\title{
高精度温度制御加熱装置による温熱治療と炎の評価*
}

\author{
円山重 直*1, 高島茂*2, 小宮 敦 樹*3 \\ 関 隆 志*4, 山家智 $之^{* 5}$
}

\section{Thermal Therapy and Evaluation by Precise Temperature Control Device}

\author{
Shigenao MARUYAMA*6, Shigeru TAKASHIMA, Atsuki KOMIYA, \\ Takashi SEKI and Tomoyuki YAMBE \\ ${ }^{*} \hat{6}$ Institute of Fluid Science, Tohoku University, \\ 2-1-1 Katahira, Aoba-ku, Sendai-shi, Miyagi, 980-8577 Japan
}

\begin{abstract}
Moxibustion, one of thermal therapy of oriental medicines, has several problems such that temperature distribution is not uniform, treatment temperature cannot be controlled and smoke is emitted. Therefore, in order to solve these problems, we developed precise thermal heat transfer control device and applied it to clinical medicine as a substitute of conventional moxibustion. Numerical simulation of temperature distribution under the skin when abdominal region is heated is carried out. The abdominal heating controller developed in this study has the effect equal to moxibustion and can heat the treatment region of human skin uniformly. The treatment effect of the device was evaluated on clinical experiment, then it was found that these devices can treat ileus, diarrhea and so on. Optimal temperature for thermal therapy was examined about parameters of sex, BMI and age. Temperature distribution of heated abdominal region is calculated by $2-\mathrm{D}$ axisymmetric model considering bio-heat generation. It is confirmed that thermal effect cannot reach the viscera from the calculation result.
\end{abstract}

Key Words: Medical Equipment, Medical Engineering, Heat Conduction, Biological Components and Systems, Bio-Heat Transfer Equation

\section{1. 緒}

尒治療は，中国を中心にアジア各地で何千年以上 の間，漢方医学における温熱治療の手法の一つしし て用いられてきた(1)。众治療は，ヨモギの葉の裏か ら取㧈るもぐさを皮膚上部で然焼させることによっ て径穴（いわゆる「ツボ」）や患部を加熱し，様々 な症状を軽減するという治療である，近年の研究に よると，急性リンバ管炎の治療において，众で患部 を温熱した状態に保つと病状の改善することや，ま た众には免疫機能を高め, 脳の血流を促進する効果 があることが提唱されている(2). また，天枢と呼ば れる腹部の経穴に众を施術すると小腸の働きが活発

\footnotetext{
* 原稿受付 2009 年 3 月 31 日.

*1 正員, フェロー, 東北大学流体科学研究所(画980-8577 仙台 市青葉区片平 2-1-1).

*2 東北大学大学院工学研究科機械知能工学専攻

*3 正員, 東北大学流体科学研究所.

** 東北大学大学院医学系研究科

*5 東北大学加噛医学研究所.

E-mail : maruyama@ifs.tohoku.ac.jp
}

になり機能が改善されるという報告がある(3).

しかし，これらの効果は経験的・臨床的に知られ ているのみで，众治療のような局所的な温熱が人体 にどの様な影響を物理的に与えるのか，众治療によ って体内の温度はどの様に変化するのかという定量 的な検討は今までなされてきていなかった。また， 众治療では定量的な温度制御ができないため，治療 における最適加熱温度や温度と治療効果の関係性に 関する十分な議論がなされてこなかった．加熱部の 温熱による人体内部の温度上昇測定は困難であるが， 高い精度で内部温度分布を推定することは外部加熱 が人体に与える影響を解明するためにも重要である。

図 1 は，本研究で隔塩众 ${ }^{[1]}$ を被験者の腹部に施術 し，众を取り除いた後の皮膚表面温度の時間変化を 示す，図には中心部の温度が $44^{\circ} \mathrm{C}$ 以になっている 場合を示している. $44^{\circ} \mathrm{C}$ 以上の加熱ではタンパク質 の変性が起こるため, 高温での長時間加熱は火傷の 危険性がある(4). 众治療では医者の経験と患者によ る自己申告により，施術温度を調節しているが，温 度に対する感覚が鈍っている患者に対しては施術時 に火傷が発生する危険性を伴う，また，隔塩炎治療 
では大量の煙が発生するため, 病院等における屋内 での施術に执いては，煙の除去などの問題も生じる.

著者らは，これまでに生体伝熱の研究において， 体表面を加熱・冷却してもある一定の領域に温度変 化が止まること尔を明らかにし，脳冷却によるてん かん診断に応用した ${ }^{(6)}$ ，また，体表面の急速泠却の 解析を行い, 冷却治療用クライオプローブの開発を 行ってきた(?).

本研究の目的は，定量的な評価が難しい従来の尒 治療において，工学的な手法を用いて定量的な評価 を行うことである，そこで，众治療の代替となる高 精度温度制御を可能とする腹部温熱制御機器を開発 し，定量的な温熱治療を可能とした．この装置を使 用して，実際に温熱治療臨床で多くの患者に対して 施術し, 治療効果を確認した後, 本機器の施術温度 を定量的に評価するために臨床実験を行い，被験者 の最適加熱温度の統計を取り，統計処理を行った。 さらに，众の治療効果の伝熱工学的义カニズムを解 明するために，二次元軸対称の生体伝熱モデルを用 いて，腹部を加熱した際に生じる内部温度分布を評 洒した。さらに，腹部の物性が内部温度分布にどの ように影響を与えるかの検討を行った。

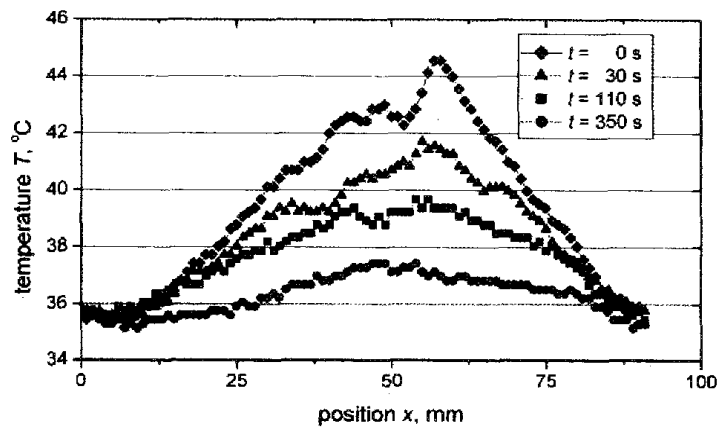

Fig.1 Variations of temperature distribution with time after the moxibustion is removed

\section{2. 腹部温熱制御栈器の開発}

図2 に本研究で開発した腹部温熱制御機器の概略 図を示す，本装置は加熱门盤と制御装置で構成され ている. 加熱円盤は直径 $100 \mathrm{~mm}$ の銅製である。熱 伝導率の高い銅を用いることで加熱面の温度を均一 にすることができる，本装置は，サ一ミス夕を用い てヒーター出力を比例制御し, 目標到達温度と昇温 速度を制御することが可能である，本装置は，目標
到達温度を超えることなく加熱円盤温度を制御する ことができ，火傷の危険性を低減させている．本装 㯰は加熱円盤の温度が $0.1^{\circ} \mathrm{C} の$ 精度で表示されるが, その表示值と害際の温度の差異を検定実験し，最適 加熱温度の高精度な統計をとることが可能である。

\section{3. 腹部温熱制御機器の性能評価}

本機器の性能を確認するために, 目標到達温度の 実現性，昇温速度と加熱後の皮膚表面温度分布の均 一性を評価した。目標到達温度を $42^{\circ} \mathrm{C}$ に設定しとき の昇温課程を図 3 に示す。図より，目標到達温度を 超えることなく目標到達温度までほぼ正確に到達し ていることが確認できた．また，加熱負荷を変化さ せることによって，舁温速度を調節できることを確 認した。

次に，本機器を被験者の腹部に施術した後，加熱 円盤を取り除いた直後の皮䖉表面温度分布の時間変 化を図 4 に示す，温度测定には赤外線画像装置

(NEC/Avio 赤外線テクノロジ一社製 TVS-500) を 用いた。図より，t=0 $\mathrm{s}$ の温度分布がほぼ均一であ る.よって，本機器は均一な温度分布で目標到達温 度まで正確に加熱できることがわかる，図 1 と図 4 を比較して，温度分布の時間変化に着目すると，本 装置では温度分布が活济均一に保ちながら減少して いることがわかる.

本装置仗，この実験の後で実際の治療施術に使用 され，煙が出ないこと，温度制御が容易で火傷の心 配がないこと，安定した温熱治療で治療効果が大き いことにより,多くの患者に治療効果をあげている. 現在では，当該病院では隔塩尒治療は本装置で行わ れ，従来の食は使用されていない。
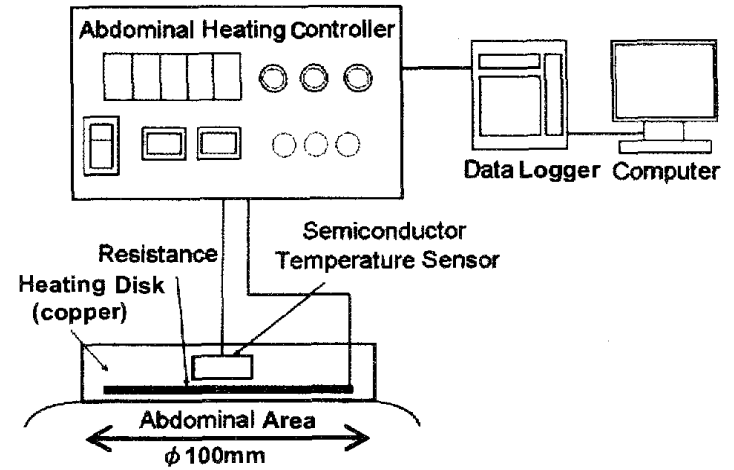

Fig.2 Schematic diagram of abdominal heating controller 


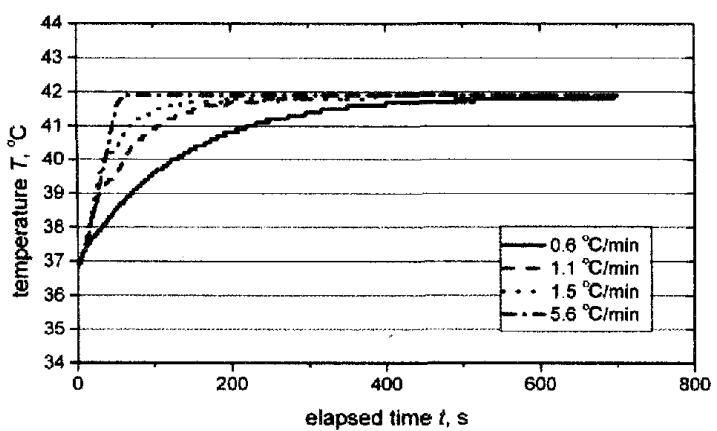

Fig.3 Variation of the incremental rate of temperature on the skin surface of the subject's abdominal area, in case that the temperature of heating disk was set at $42^{\circ} \mathrm{C}$

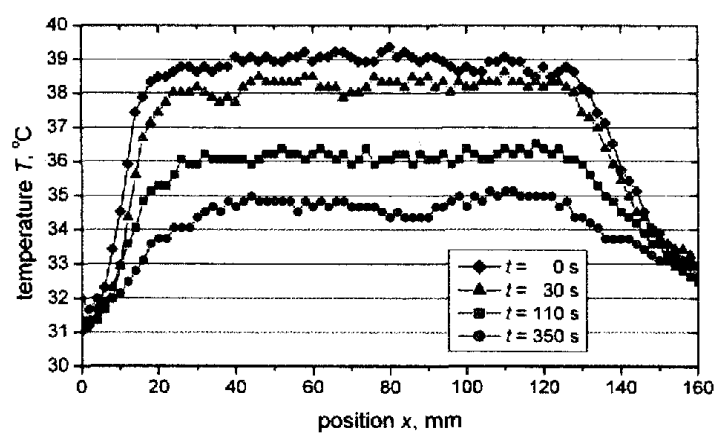

Fig. 4 Variations of temperature distribution with time on the contact-type abdominal heating controller

\section{4. 臨床実験と統計結果}

众治療では，患者が「気持ちがよい」と感じる温 度が治療効果も高いとされ，この温度が最適加熱温 度といわれている，従来の尒では，最適加熱温度の 設定は医師と患者との対話でなされてきたが，本装 置は高精度な温度制御が可能なので, あらかじめ最 適加熱温度が推定できれば, より効率的な治療が可 能であると考えられる.

そこで, 臨床で多くの患者に対して施術し最適加 熱温度と被験者の条件について統計をとった. 被験 者の条件については, 性別, 年齢, BMIについて整 理した.ここで, 最適加熱温度とは, 患者が加熱に 対して快適と感じる温度である.

図 5 に患者 1 人に対する最適加熱温度と施術回数 の関係を示す．最適加熱温度の分布に着目すると， 施術の度に, 毎回異なる值をとっていることが確認 できる.これは，施術を行う際の周囲温度や湿度， 体調，気分ならびに治療による快復度に依存すると 考えられる. この患者の場合, 最大で $5^{\circ} \mathrm{C}$ 差が生 じているので，その影響は大きいと考えられる.こ
のように，最適加熱温度では各個人におうても差が 生じるために, 以後の統計結果では各被験者に対す る最適加熱温度の平均値を用いた. また, 被験者 1 人に対する最適加熱温度について，不確かさ区間を 求め評価を行った ${ }^{(4)}$. 複数回施術を行った被験者に 対して, 最適加熱温度平均値を中心とした不確かさ 区間を示した。

最適加熱温度は体型に依存する可能性がある。そ こで, BMI（ボディマス指数）を評価のパラメータ として検討した. BMI は，体型評価の指標であり，

$$
\mathrm{BMI}=\frac{w}{h^{2}}
$$

で与えられる.ここで, $w[\mathrm{~kg}]$ は被験者の体重, $h[\mathrm{~m}]$ は身長を表す. BMI 指数の標準值は 22 であり, 18.5 未満はやせ型，25以上は肥満に分類される. 図6に 男女 17 人に対する最適加熱温度と BMI の統計結果 を示す. 個人に対して 1 回から 32 回の施術を行った 結果を統計処理している.図6から明らかなように， 最適加熱温度は，男女間に汇有意差がない，BMI と の関係についても有意な傾向がない。こ机より，体 型は最適加熱温度に影響を及ぼさないと考えられる。

次に，図 7 に男女 39 人に対して測定した最適加熱 温度と年齢の関係を示す。図中には，最小二乗法に より最適加熱温度と年齢の関係の相関を示した．図 より，高年龄の被験者ほど，最適加熱温度が高くな っている.これは，高齢になると温度感知が鈍るた めに, 最適過熱温度が高くなると考えられる. 最小 二乗法による採用式は次式で表される.

$$
T_{o p t}=0.00308 y+40.3
$$

ここで, $y$ は年齢, $T_{o p t}\left[{ }^{\circ} \mathrm{C}\right]$ は最適加熱温度を示す.

本研究の統計結果は, 臨床において本機器を施術 する際の施術温度の指標になると考えられる。

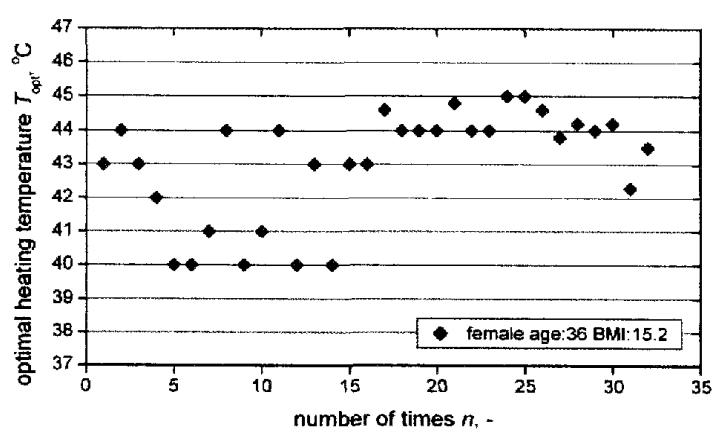

Fig.5 Statistical results of optimal heating temperature of one patient 


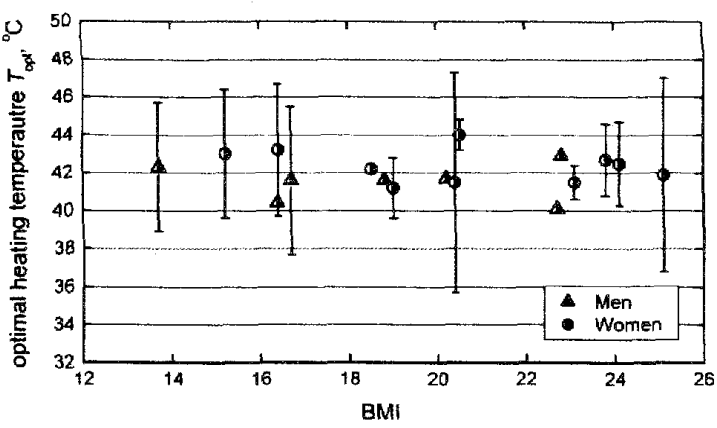

Fig.6 Relationship between optimal temperature and BMI.

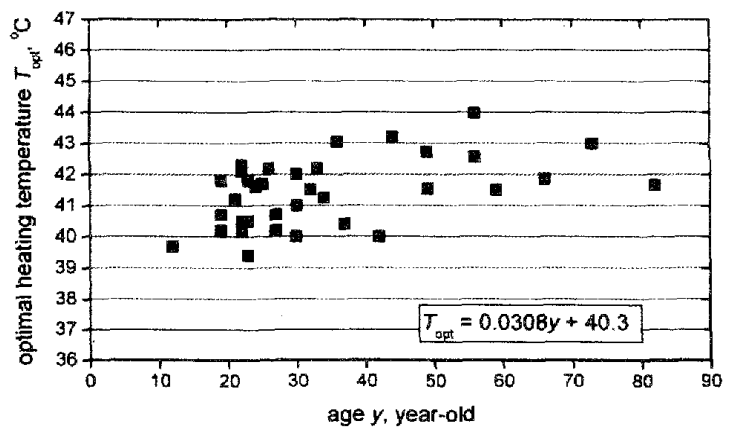

Fig.7 Relationship between optimal temperature and age.

\section{5. 内部温度分布の数值解析}

図8に本研究で用いた腹部伝熱の数值解析モデル を示す.モデルは二次元軸対称とし, 図8 に示すよ うに多層構造とする，腹部の各層の厚さは，皮膚が $0.4 \mathrm{~mm}$, 脂肪層が $7.8 \mathrm{~mm}$, 筋肉層が $13.4 \mathrm{~mm}$ とし, 笳肉層よりも深い層は内臓層とした ${ }^{(8)}$. 支配方程式 にはPennes の生体伝熱の式を用いた ${ }^{(9)}$.

$\rho c \frac{\partial T}{\partial t}=\frac{1}{r} \frac{\partial}{\partial r}\left(k r \frac{\partial T}{\partial r}\right)+\frac{\partial}{\partial z}\left(k \frac{\partial T}{\partial z}\right)+\rho_{b} c_{h} \omega_{h}(T)\left(T_{u}-T\right)+\dot{q}_{m e t}(T)$

ここで $T\left[{ }^{\circ} \mathrm{C}\right]$ は温度, $t[\mathrm{~s}]$ は時間, $\rho\left[\mathrm{kg} / \mathrm{m}^{3}\right]$ は密 度, $c\left[\mathrm{~J} /\left(\mathrm{kg} \cdot{ }^{\circ} \mathrm{C}\right)\right]$ は比熱, $k\left[\mathrm{~W} /\left(\mathrm{m}^{\circ}{ }^{\circ} \mathrm{C}\right)\right]$ は熱伝導率, また下添え字で $a$ は動脈， $b$ は血液を表す。 $\omega_{b}[1 / \mathrm{s}]$ は血液灌流率で単位体積の生体組織に流入する血液 流量を表す，右辺第三項は血流と組織との熱交換を 表し，右辺第四項注代謝による発熱を表している. 本研究では血液灌流率と代謝による発熱が温度に依 存するとし，以下の関係式を用いた(6).

$$
\begin{aligned}
& \omega_{b}(T)=\omega_{0} Q_{10}{ }^{\left(T-T_{o}\right) / 10} \\
& \dot{q}_{\text {met }}(T)=\dot{q}_{0} Q_{10}{ }^{\left(T-T_{a}\right) / 10}
\end{aligned}
$$

初期温度分布は実験より初期表面温度が $34^{\circ} \mathrm{C}$ で あることから，これを境界条件として表面に与えて 定常計算したものを用いた，また，表面における境 界条件は加熱円盤温度を $42^{\circ} \mathrm{C}$ に設定して温度上昇 させた実験デ一夕を与え，それ以外の場所は自然対 流とふく射による熱伝達境界条件を用いた(11).

$$
h_{t}=h_{c}+4 \varepsilon \sigma T_{m}^{3}
$$

ここで $h_{c}\left[\mathrm{~W} /\left(\mathrm{m}^{2} \cdot \mathrm{K}\right)\right]$ は自然対流による熱伝達条件, 右辺第 2 項は有效及<射熱伝達率 ${ }^{(10)}, \sigma\left[\mathrm{W} /\left(\mathrm{m}^{2} \cdot \mathrm{K}^{4}\right)\right]$ はステファンボルツマン定数, $T_{\mathrm{m}}[\mathrm{K}]$ は皮膚表面温度 である. 皮膚表面以外の境界条件は断熱とした。

図 9 は加熱円盤温度を $42^{\circ} \mathrm{C}$ に設定して温度上昇 させた実験デー夕を与えて $900 \mathrm{~s}$ 間, 腹部を加熱後, 加熱円盤を離して自然放熱をさせた場合の体内温度 分布である． $1000 \mathrm{~s}$ の温度分布に着目すると，脂肪 層内部に温度分布が生じているのがわかる。これは 脂肪層内の熱伝導よりも周囲との熱伝達が大きく, 表面が急速に冷えるために生じると考えられる。ま た加熱円盤温度を $42{ }^{\circ} \mathrm{C}$ に設定して，腹部を 15 分間 加熱しても内臓温度はほとんど温度上昇していない ことがわかる。

図 10 は $42^{\circ} \mathrm{C}$ で定常状態になるまで腹部を加熱し た場合の計算結果である，定常状態においても，内 臓と筋肉の境界面の温度は体温に対して $0.3^{\circ} \mathrm{C}$ しか 上昇していない。

以上の結果から，本装置で腹部の加熱による「体 の芯まで温まると感じる」現象は，実際上では内臟 温度はほとんど上昇しない，従って，温熱治療の効 果は，内臟温度が上昇するというより，皮膚近傍の 昇温などが自律神経に作用し内臟機能が活発化して 得られるのではないと考えられる。著者らの研究に よると，腹部温熱により皮膚表面の血流が活発化さ れることが测定されていること，腹部温熱を施術す ると上腸管膜動脈や时動脈の血流が上昇すること (11)からも，自律神経の作用など他の要因によって， 間接的に内臓機能が改善されると推測される。 


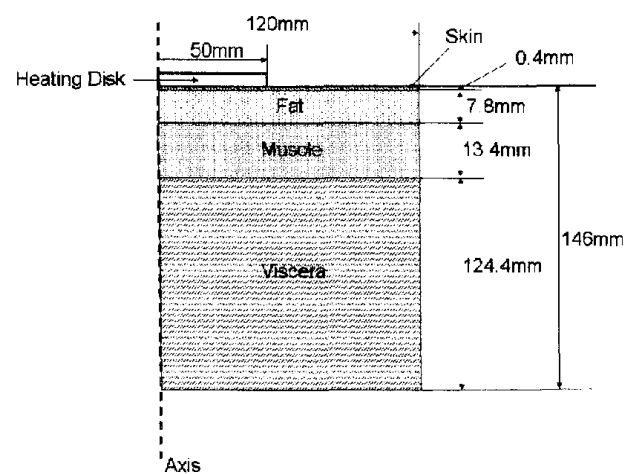

Fig.8 2-D axisymmetric multiple layer model of abdominal area

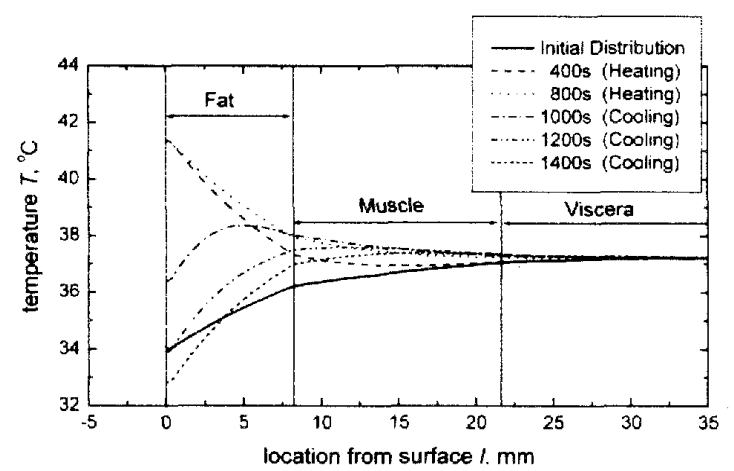

Fig. 9 Temperature Distribution in abdominal region

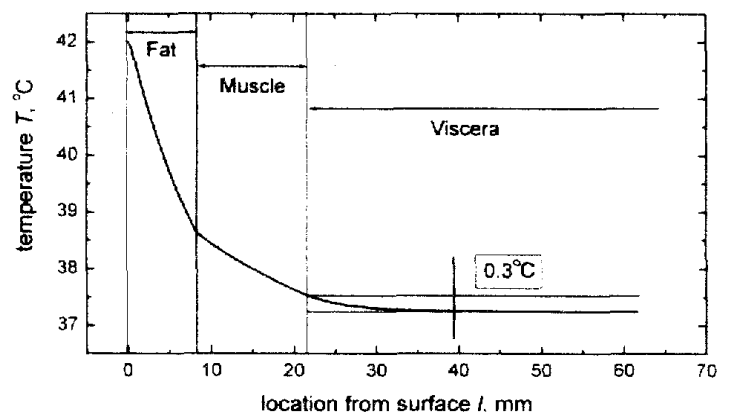

Fig.10 Temperature Distribution at Steady State

\section{6. 結}

本研究では，伝統的な曶治療効果を伝熱工学的手 法で解明するために高精度で温度制御可能な加熱装 置を用いて, 次の知見を得た。

1. 高精度温度制御が可能な腹部温熱制御装置を開 発した，本装置により，これまでの众治療では 不可能だつた温熱治療の施術温度を定量的に評 価することができた.

2. 本装置を用いて臨床実験を行い，最適加熱温度 と患者の条件に関して統計処理を行った．最適 加熱温度について，不確かさ区間の個体差が大 きいことを示した. また, 最適加熱温度と性別, BMI の間には相関が見られなかったが，年齡に
関しては高齢になるほど最適加熱温度が高くな る傾向を示した。

3. 腹部温熱制御機器を施術した際の体内温度分布 を計算し，腹部を加熱しても内臓はほとんど温 度上昇しない可能性を示した．温熱治療の効果 は，温熱による自律神経の作用などにより，間 接的に内臟機能が活発化して得られるのではな いと考えられる。

\section{文 献}

(1) Ozaki, A, Schematic manual of clinical procedure on acupuncture and moxibation therapy (in Japanese) , (2003). Ishiyaku Pablishers

(2) Shen, X, Ding, G., Wei, J., Zhao, L., Zhou, Y., Deng, $H$. and Lao, L., An infrared radiation study of the biophysical characteristics of traditional moxibustion, Complementary Therapies in Medicine, Vol.14 (2006), pp.213-219.

(3) Tabosa, A., Yamamura, Y., Forno, E.R and Mello, L.E.A.M, A Comparative Study of the Effects of Electroacupuncture and Moxibution in the Gastriintestinal Motility of the Rat, Digestive Diseases and Sciences, Vol.49, No.4 (2004), pp.602-610.

(4) Ng, E.Y.K and Chua, L.T., Comparison of One- and Two-Dimensional Programmes for predicting the State of Skin Burns, Bums, Vol.28 (2002), pp.27-34.

(5) Maruyama, S., Okajima, J., Komiya, A. and Takeda, H. Estimation of Temperature Distribution in Biological Tissue by Using Solutions of Bioheat Transfer Equation, Heat Transfer -Asian Research, Vol.37, No.6 (2008), pp.374-386.

(6) Maruyama, S., Takeda, H., Komiya, A., Yambe, T. and Nakasato, N., Brain Mapping Method Utilizing Rapid Cooling Probe, Proceeding of the 17th International Symposium on Transport Phenomena, (2006-9), 1-D-I-4.

(7) Takeda, H., Maruyama, S., Okajima, J., Aiba, S. and Komiya, A., Precise Control of Cooling and Heating Rate Utilizing Peltier Cryoprobe for cryosurgery, Proceedings of the 19th International Symposium on Transport Phenomena, (2008-8), No.141(CD-ROM).

(8) Samaras, T., Christ, A. and Kuster, N., Effects of geometry discretization aspects on the numerical solution of the bioheat transfer equation with the FDTD technique, Physics in Medicine and Biology, Vol.51, (2006), N211-N229.

(9) Pennes, H.H., Analysis of Tissue and Arterial Blood Temperatures in the Resting Human Forearm, Journal of Applied Physiology, vol.1, No.2 (1948),pp.93-122.

(10) The Japan Society of Mechanical Engineers ed. JSME Textbook Series : Heat Transfer, (2005), The Japan Society of Mechanical Engineers.

(11)Takayama, S., et al., Changes of blood flow volume in the superior mesenteric artery and brachial artery with abdominal thermal stimulation, Evidence-based Complementary and Alternative Medicine, (2009), to be published. 